\title{
A palavra do reitor
}

FLÁVIO FAVA DE MORAES

ontribuindo para as comemoraçōes dos 60 anos da Universi-
dade de São Paulo, Estudos Avanģados lança esta ediçáo espe-
cial com dois propósitos: relembrar parte da história da USP
e informar sobre nossas linhas de pesquisa nas áreas de humanidades e
de ciências básicas.

Náo se pretende, aqui, apresentar um retrato total da USP, nem relatar sobre tudo o que é feito nas Unidades ou nos múltiplos serviços que prestamos à coletividade. Aparecem com destaque o nascimento e a evoluçăo da velha Faculdade de Filosofia, Ciências e Letras, porque foi criada pelo mesmo ato governamental de janeiro de 1934 e porque recebeu a missão de desenvolver o trabalho de pesquisa nas ciências básicas e nas humanidades. Este número especial apresenta, também, informaçóes sobre os institutos que, de uma forma ou de outra, tiveram como origem as seçóes de História Natural, Física, Química e Matemática da FFCL. Por isso, em seu conjunto, esta edição de Estrudos Apanf̧ados é uma preciosa coletânea de informaçōes sobre a história da USP e sua realidade atual.

O que se pode concluir sobre a história da USP e o papel que vem desempenhando no cenário nacional nestas seis décadas? Em resumo, creio que o substancial foi sua contribuição decisiva para a execução e modernização da Ciência no Brasil. É claro que antes de 1934 já havia atividade científica no Brasil, pelo menos em algumas áreas muito importantes. Jamais seráo olvidados, por exemplo, os pioneiros trabalhos científicos em Manguinhos, no Butantan, no Agronômico, na Esalq, no Biológico, nas faculdades de Medicina do Rio e de Sáo Paulo, na Politécnica etc., mas a Ciência moderna inicia-se no país com a criação da USP e quando para ela veio um grupo de professores estrangeiros, dedicados integralmente à missão de formar pesquisadores, trazendo como bagagem, em várias áreas, a experiência universitária européia.

Assim começou a façanha da USP, que vingou graças à clarividência daqueles que a idealizaram e a implantaram - educadores, cientistas, intelectuais e estadistas, entre os quais Júlio de Mesquita Filho, Armando de Salles Oliveira, Fernando de Azevedo, André Dreyfus, Teodoro Ramos, Paulo Duarte, Rocha Lima, entre outros. 
Esta façanha é o resultado de muito esforço e tenacidade, de êxitos para superar revezes transitórios, de luta contra interesses mesquinhos e atraso cultural. É o resultado, enfim, de $\mathbf{6 0}$ anos de esforços continuados de várias geraçóes de docentes e de funcionários, que contaram com a firme determinaçáo de administradores do estado de Sáo Paulo de aplicar vultosos recursos do erário para a construçáo de um patrimônio cultural no mesmo nível das $\mathbf{1 0 0}$ melhores universidades do mundo.

Em seis décadas apenas, partindo de instalaçóes emprestadas e acanhadas, de laboratórios improvisados, amalgamando algumas instituiçóes já consolidadas com o projeto e a realidade de uma Faculdade de Filosofia, Ciências e Letras, assim foi sendo criada a USP no campus da capital e nos campi do interior.

É com orgulho que falamos da USP, mas sempre temos presente a responsabilidade de aperfeiçoá-la, porque hoje e amanhã temos de cumprir uma missáo qualitativamente superior.

Em meu discurso de posse como reitor, no ano passado, procurei definir o que penso ser nossa missáo na USP. É a paixão de fazer sempre o melhor, o compromisso de vida com os valores da excelência e da liberdade de espírito, de indagar sobre todas questóes, de escolher livremente os caminhos da pesquisa. É o dever de cultivar a permanência das linhas substanciais da USP, mas, também, em aparente paradoxo, o dever para com a mudança desses valores, porque a liberdade de indagaçáo implica renunciar às certezas, ao já conhecido, ao já estabelecido.

Tal compromisso será alcançado se valores éticos presidirem nossos atos. A ética de abdicar dos interesses de grupos e de individualidades que se colocam acima das finalidades da instituição; a ética de combater o pacto da mediocridade, que defende o grupo contra a competiçáo externa e contra as exigências de um desempenho sempre mais alto.

Que linhas mestras apontamos para o futuro próximo? É a confirmaçáo de um projeto acadêmico voltado para a valorizaçáo do capital humano da USP; a descentralizaçáo e desburocratizaçáo administrativa; a plena reintegração dos colegiados à sua função pluralista de definir a política acadêmica e a inserção da USP nos grandes debates nacionais; a adoçáo de uma política de ensino inovadora e mais adequada às expectativas de nossos alunos e às demandas da sociedade; e uma política de pesquisa que seja, ao mesmo tempo, pautada por critérios qualitativos e integrada às necessidades sociais e econômicas do país. 
A USP completou 60 anos. É a maturidade plena, equilibrada, sólida. Não se pode mais falar em desenvolvimento brasileiro e, em especial, paulista, sem se considerar o papel da USP. Entretanto, mais do que um compromisso com o passado, essa maturidade inspira o desafio de traçar, desde já, o nosso futuro, sempre renovado na continuidade das geraçóes.

Flatrio Fava de Mornes é reitor da Universidade de Săo Paulo. 